\title{
Blue whale (Balaenoptera musculus) sightings off the coast of Virginia
}

\author{
Dan T. Engelhaupt ${ }^{1 *}$, Todd Pusser ${ }^{2}$, Jessica M. Aschettino ${ }^{1}$, Amy G. Engelhaupt ${ }^{3}$, Mark P. Cotter ${ }^{1}$, \\ Michael F. Richlen ${ }^{1}$ and Joel T. Bell ${ }^{4}$
}

\begin{abstract}
We report on two sightings of individual blue whales (Balaenoptera musculus) off the coast of Virginia during marine mammal surveys. On 11 April 2018, during a vessel survey off the coast of Virginia, a single blue whale was observed approximately $100 \mathrm{~km}$ east-northeast of Virginia Beach. On 10 February 2019, another single blue whale was recorded during an aerial survey approximately $135 \mathrm{~km}$ east-southeast of Virginia Beach. These observations mark the first time this endangered species has been documented with photographs off the coast of Virginia, and represent the southernmost confirmed sightings in waters of the United States Atlantic Exclusive Economic Zone (EEZ). At the time of the vessel observation, numerous fin whales (Balaenoptera physalus), humpback whales (Megaptera novaeangliae), and North Atlantic right whales (Eubalaena glacialis), were observed within the same approximately $8 \mathrm{~km}^{2}$ area as the blue whale. For the aerial sighting, the blue whale was seen feeding among at least 15 fin whales in an area approximately $4 \mathrm{~km}^{2}$. These sightings contribute to the small body of information existing for the late winter/early spring distribution of blue whales in waters of the western North Atlantic.
\end{abstract}

Keywords: Blue whale, Balaenoptera musculus, Virginia, Mid-Atlantic, Western North Atlantic, U.S. Navy, Cetacean

\section{Introduction}

The blue whale (Balaenoptera musculus) is the largest baleen whale, and the largest creature ever to inhabit the earth (Jefferson et al. 2018). Aside from a long-term study in the Gulf of Saint Lawrence (Sears et al. 1990; Lesage et al. 2017), relatively little is known about the species distribution, foraging areas, habitat preferences, and movements in the western North Atlantic, where the population size remains low as a result of decades of commercial whaling (Sergeant 1966; Mitchell 1974). By reviewing historical records from the logbooks of whalers, Reeves et al. (2004) found that blue whales have a broad distribution in the North Atlantic, generally feeding at higher latitudes during the spring and summer, and moving south into temperate and tropical waters during the fall and winter.

\footnotetext{
* Correspondence: Daniel.Engelhaupt@hdrinc.com

${ }^{1}$ HDR, 4144 Hermitage Point, Virginia Beach, VA 23455, USA

Full list of author information is available at the end of the article
}

Blue whales are considered to be occasional visitors to United States (U.S.) Atlantic Exclusive Economic Zone (EEZ) waters; however, reports of the species from this region in the scientific literature are rare. True (1904) documented the Eastern Seaboard's southernmost stranding of a $22.2 \mathrm{~m}$ individual in Ocean City, New Jersey, in October 1891; the bones of which were displayed at the Philadelphia Academy of Natural Sciences. There are two unconfirmed strandings of blue whales reported from the Gulf of Mexico. On 17 August 1940, a $21.3 \mathrm{~m}$ baleen whale stranded alive on the Texas coast between Freeport and San Luis Pass. Photos published of the whale in local newspapers led Baughman (1946) to believe the specimen in question was a blue whale. However, no skeletal remains of the animal were salvaged, and the photos collected at the time of the stranding lack sufficient quality to confirm identification. A stranding of a purported fin whale near Sabine Pass, Louisiana, in early December 1924 was subsequently identified as a blue whale by various authors (Schmidly

(c) The Author(s). 2020 Open Access This article is licensed under a Creative Commons Attribution 4.0 International License, which permits use, sharing, adaptation, distribution and reproduction in any medium or format, as long as you give

appropriate credit to the original author(s) and the source, provide a link to the Creative Commons licence, and indicate if changes were made. The images or other third party material in this article are included in the article's Creative Commons licence, unless indicated otherwise in a credit line to the material. If material is not included in the article's Creative Commons licence and your intended use is not permitted by statutory regulation or exceeds the permitted use, you will need to obtain permission directly from the copyright holder. To view a copy of this licence, visit http://creativecommons.org/licenses/by/4.0/. 
1981). Two photos of this specimen published in Lowry (1974) are indeed suggestive of a blue whale, but due to the angle in which the images were made, it is difficult to rule out other balaenopterids. No skeletal material was salvaged from this specimen.

Wenzel et al. (1988) describe three sightings of blue whales from the Gulf of Maine. The sightings were, at the time, the southernmost live, non-stranded blue whales, confirmed with photos in the western North Atlantic documented in the scientific literature. Sighting records assembled during the Cetacean and Turtle Assessment Program at the University of Rhode Island (CETAP 1982) included two "possible" blue whale sightings in deeper waters of the EEZ in the Mid-Atlantic region on 1 April 1969 , though neither had associated photographs to confirm species identity. One blue whale was sighted from a whale-watch boat on three different occasions (believed to be the same individual each time) between 24 July and 3 August 1990, 20 to $30 \mathrm{~km}$ off Montauk Point, New York (Kenney and Vigness-Raposa 2010).

Recently, two satellite-tagged female blue whales from the Gulf of Saint Lawrence were shown to move into offshore waters of the Mid-Atlantic Bight, far from the edge of the continental shelf, during the months of December to March (Lesage et al. 2017). One of these whales transited along the edge of the continental shelf off Virginia before continuing south to within $45 \mathrm{~km}$ of Cape Hatteras, North Carolina, and finally down to an area $400 \mathrm{~km}$ east of Charleston, South Carolina, before turning around and moving back north (Lesage et al. 2017).

Using hydrophone arrays from the U.S. Navy's Integrated Undersea Surveillance System, Clark (1995) was able to acoustically track a single blue whale from waters off Newfoundland, south and well outside the EEZ, to the subtropical waters of the northern West Indies. Additionally, blue whale calls were recorded over a period of 2 days during the winter of 2015 on a High-frequency Acoustic Recording Package (HARP) deployed in Norfolk Canyon, approximately $112 \mathrm{~km}$ east of Virginia Beach (Hodge et al. 2016). HARPs have been deployed at this site since 2015, and data have been analyzed through early June 2018. The HARPs record continuously and only 2 days had blue whale detections, 25 January and 20 February 2015. While blue whale signals have been modeled to travel very long distances and measured at a range up to $200 \mathrm{~km}$ on similar bottommounted devices (Širović et al. 2007), the site specific detection range for the Norfolk Canyon HARP has not been determined; however, whales are likely detectable many kilometers away. Additional HARPs located off Cape Hatteras and Onslow Bay (approximately 220 and $350 \mathrm{~km}$ south of Norfolk Canyon, respectively), North Carolina recorded occasional blue whale signals from late summer through early fall in consecutive years from
2010 through 2018, with the exception of 2015 when no sounds were detected (Hodge et al. 2015, 2016; Debich et al. 2016; Rafter et al. 2018a, b). Farther south, another deep-water HARP deployment briefly detected the presence of blue whales in July 2016 (Rafter et al. 2018a). The function of blue whale sounds is still uncertain, and the short durations of recording periods could simply indicate that animals are transiting in these areas.

Here we provide evidence via visual validation coupled with behavioral observations of two confirmed blue whale sightings. These sightings are valuable data regarding the species distribution and regional occurrence within an area of increasing anthropogenic activities.

\section{Materials and methods}

Funded by U.S. Fleet Forces Command and managed by the Naval Facilities Engineering Command Atlantic under the U.S. Navy Marine Species Monitoring Program, scientists from HDR conduct year-round vessel and aerial surveys in the offshore waters of Virginia to document the presence and habitat use of marine mammal and sea turtle species in naval training and testing areas. Boat-based field observations were undertaken from 2015 to 2019 using $15-17 \mathrm{~m}$ charter vessels for single-day non-systematic surveys. While in search mode, four experienced marine mammal observers scanned 360 degrees around the vessel by eye and with the aid of 10x binoculars. Duration and extent of search effort varied based on multiple factors, including short breaks to avoid observer fatigue and primary project goals associated with deploying satellite-monitored tags on key species of interest. Data recorded for each marine species sighting included the time, position, water depth, species, group size, group behavioral state, and an initial range and relative bearing to the sighting. Coverage was not systematic and routes were determined and adjusted based on a variety of factors, including desired seasonal coverage of all areas, previous or reported priority sightings, Navy range closures, and optimal weather conditions. Photographs were collected whenever possible using a Canon 7D Mark II camera and a $100-400 \mathrm{~mm}$ telephoto zoom lens.

HDR also conducted bi-monthly standard line-transect aerial surveys from April 2018 through August 2019 in waters between approximately 80 and $160 \mathrm{~km}$ offshore of Virginia. A Cessna-337 Skymaster was used for all surveys, with two pilots and two experienced observers who scanned each side of the trackline continuously for all species of marine mammals and turtles. The aircraft was flown at 100 knot speed and $305 \mathrm{~m}$ altitude. Photographs were taken with a Canon 1DX Mark II equipped with a 100-400 $\mathrm{mm}$ telephoto zoom lens. Whenever possible, coordination with the HDR vessel survey team 
was attempted to maximize the survey potential of sightings between platforms.

\section{Results and discussion}

At 1315 Eastern Daylight Time, on 11 April 2018, a single blue whale was observed during a vessel survey at $37.1888^{\circ} \mathrm{N}$ and $74.8409^{\circ} \mathrm{W}$, approximately $100 \mathrm{~km}$ eastnortheast of Virginia Beach (Fig. 1). Sea surface temperature at the time of the sighting was $7.5^{\circ}$ Celsius, and the water depth was $53 \mathrm{~m}$. Photographs (Fig. 2) obtained during the sighting clearly show the diagnostic characteristics of the species, including a tall, columnarshaped blow, a broad head, a small dorsal fin relative to body size set far back on a long body, and distinctly mottled blue-gray coloration (Jefferson et al. 2018).

Other large baleen whales were sighted in the same general viewing area as the blue whale were sighted, including at least three fin whales (Balaenoptera physalus), four humpback whales (Megaptera novaeangliae), and two North Atlantic right whales (Eubalaena glacialis). Since it was smaller than the adult fin whales in the vicinity, the blue whale was considered to be a juvenile. The whales were diving asynchronously and continually moving in varying directions, making it difficult to follow any particular animal for more than a few minutes. After the initial detection and photographs, the blue whale was observed making three surfacings, then dove and was lost among nearby whales. Despite fair viewing conditions (Beaufort Sea State 3 and swell height of less than 1 meter) and the vessel remaining in the area for over an hour, the blue whale was not re-sighted.

At 0915 Eastern Standard Time, on 10 February 2019, a sighting of a single adult blue whale was recorded during an aerial survey at $36.7928^{\circ} \mathrm{N}$ and $74.4535^{\circ} \mathrm{W}$, approximately $135 \mathrm{~km}$ east-southeast of Virginia Beach. Water depth at the sighting location was approximately $1700 \mathrm{~m}$. The individual was foraging within a group of at least 15 fin whales, which were spread out over an area approximately $4 \mathrm{~km}^{2}$ in size. The aircraft circled the whale and prior to its dive obtained identification photographs (Fig. 3) that show the tall, columnar blow, broad U-shaped rostrum, large splashguard, blue-gray mottled coloration, and ratio of pectoral fin size relative to body length (Jefferson et al. 2018). The aircraft remained in the vicinity for $10 \mathrm{~min}$ photographing individual fin whales before returning to the trackline to resume systematic survey effort. The blue whale was not re-sighted a second time. Based on a comparison of photos, the whale from the 2018 vessel survey was confirmed as a different individual than the whale photographed during the 2019 aerial survey.

The images obtained of the blue whales were compared with those of known individuals in the western North Atlantic Blue Whale catalog maintained by
Mingan Island Cetacean Study (MICS, Longue-Pointede-Mingan, Québec, Canada). No matches were found for the individual sighted during the 11 April 2018 vessel survey (Richard Sears, MICS, personal communication). The blue whale sighted during the 10 February 2019 aerial survey was matched to a known individual previously observed in the Gulf of St. Lawrence (Richard Sears, MICS, personal communication).

The two sightings off the coast of Virginia are the first to corroborate that the signals recorded on the stationary HARP unit may not necessarily be coming from distant animals. Although no blue whale vocalizations were recorded on the HARP at the Norfolk Canyon site during the time of the April 2018 vessel sighting, the acoustic recording data has yet to be analyzed for the period associated with the February 2019 aerial survey sighting. It should be noted that a lack of recorded blue whale vocalizations on the HARP does not mean whales are not present within the geographic area surrounding the unit; rather, they may be present but in areas with poor signal propagation to the sensor (e.g. on the shelf) or simply not vocalizing. Previous studies have demonstrated that blue whales do not call frequently when foraging (Calambokidis et al. 2007; Oleson et al. 2007). Both of the individuals described here were observed near confirmed feeding aggregations and, for those that may be present in this region, this could explain the paucity of acoustic detections made on the nearby HARP.

The sightings of blue whales in waters off Virginia, though brief, offer interesting insights into their otherwise poorly known winter and spring movements. Foraging in mid-latitude waters by blue whales during their migratory cycle has been reported in studies of satellitetagged whales in the Northeast Pacific (Bailey et al. 2009), and it is plausible that the energetic costs associated with foraging are offset when opportunistically feeding in areas of temporally high-density prey. Two days prior to the vessel observation, an aerial survey conducted by HDR on 9 April 2018, had found multiple species of baleen whales in the same general, shallowwater area, including numerous humpback whales, fin whales, common minke whales (Balaenoptera acutorostrata), and at least five additional North Atlantic right whales (photographs confirmed that four of these were different individuals from those seen on 11 April). Photos obtained from the plane that day documented a group of five bubble-net feeding humpbacks and two different right whales feeding sub-surface.

On 11 April, many of the same species were still present in the general vicinity, and one of the right whales defecated at the surface, suggesting recent feeding, near the location of the blue whale. It is likely that the whales, including the blue whale, were drawn to the area by an abundant food resource. 


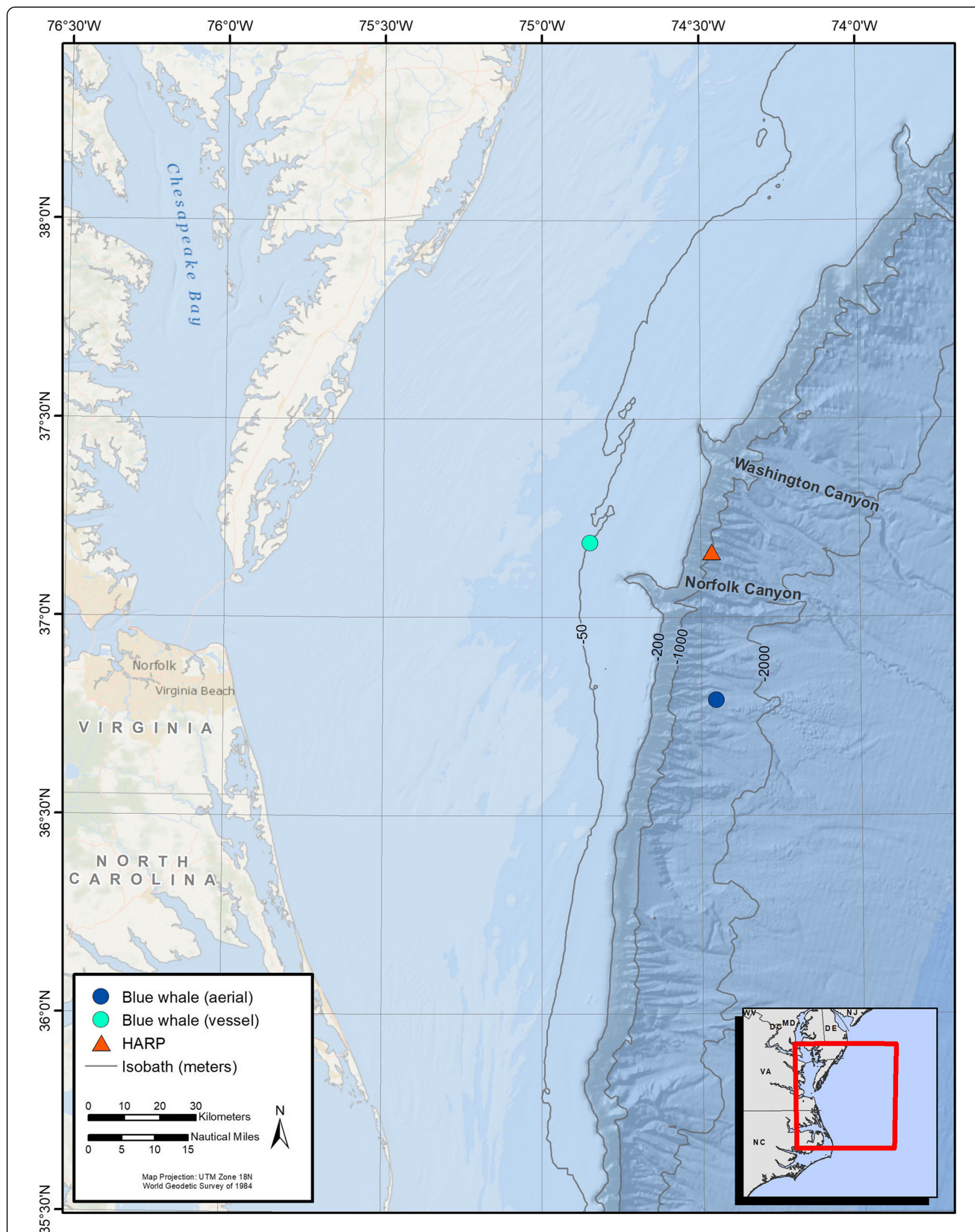

Fig. 1 Sighting locations of blue whales from aerial (blue dot) and vessel (green dot) surveys. The location of the High-frequency Acoustic Recording Package (HARP) is indicated by the orange triangle 



Fig. 2 Surfacing sequence of a blue whale observed during vessel survey on 11 April 2018, showing the tall, columnar blow and broad head (a), as well as the distinctly mottled, blue-gray coloration, and small dorsal fin relative to body size set far back on a long body (b, c, \& $\mathbf{d})$

Though the offshore waters of Virginia are outside the known foraging areas of some of the species in this observation, evidence in other areas of the world has shown that numerous species of baleen whales will take advantage of locally abundant food resources along their migratory routes (Visser et al. 2011; Silva et al. 2013). The waters off southeastern Virginia can be highly dynamic, with eddies from the Gulf Stream farther offshore affecting local currents along the continental shelf (Lee et al. 1991). Continental shelf break waters and deep water canyons, such as Norfolk Canyon, can also be highly dynamic and are widely known as areas of enhanced productivity (Atkinson et al. 1984). Furthermore, the region is influenced by a tidal outflow plume from the Chesapeake Bay, which itself is fed by numerous large rivers (Filippino et al. 2009). Perhaps these environmental conditions periodically combine to create localized areas of enhanced productivity, as documented by Malone and Ducklow
(1990), which in turn, may provide temporary feeding grounds for large whales.

Our observations, combined with recent acoustic recordings and Argos positions from tagged animals (Lesage et al. 2017), suggest that a small number of blue whales may use Mid-Atlantic waters within the U.S. EEZ, including those off Virginia, at least during the winter and early spring. In addition to climate change, an array of anthropogenic activities, including commercial and recreational fishing, regular transiting of large commercial and military vessels into and out of nearby Chesapeake Bay, recreational boating, and frequent naval training and testing activity may impact many species of whales, including blue whales as has been described in this and other oceanic regions (Aschettino et al. 2020; Forney et al. 2017; Rockwood et al. 2017; Southall et al. 2019; Tulloch et al. 2019). Recent proposed coastal energy development throughout the region, in the form of wind farms and seismic surveys that precede the drilling of natural gas and 


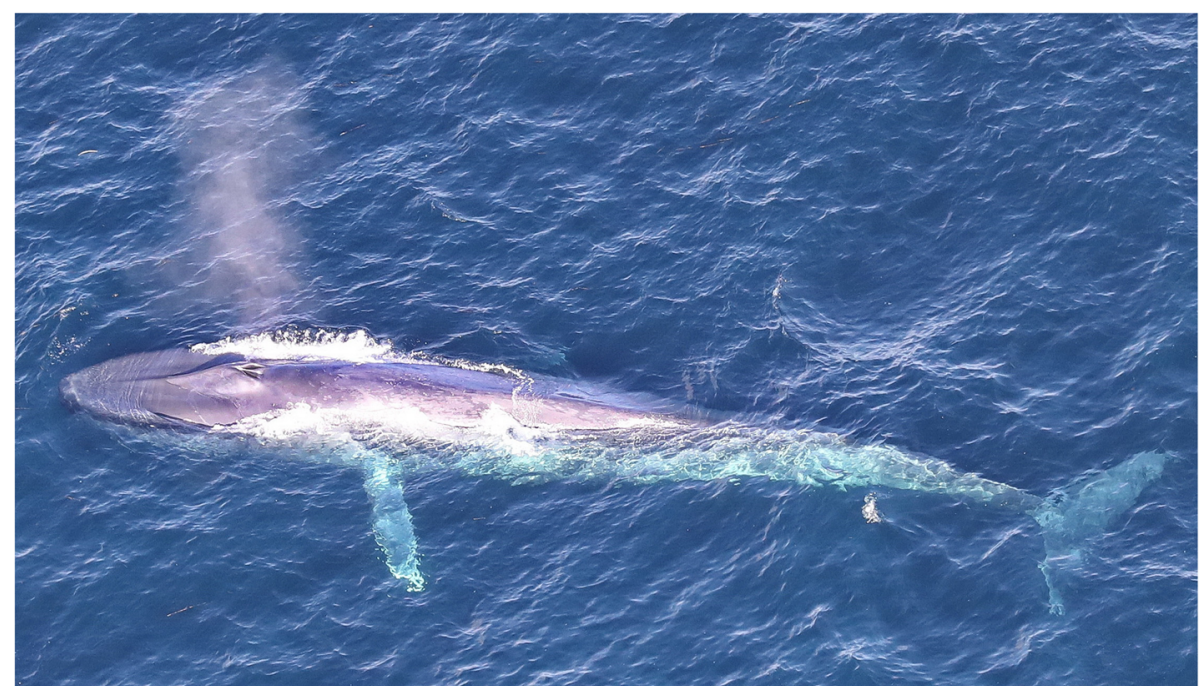

Fig. 3 Aerial image taken of a blue whale on 10 February 2019 that shows the tall, columnar blow, broad U-shaped rostrum, large splashguard, blue-gray mottled coloration, and ratio of pectoral fin size relative to body length

oil, may also affect the movement, foraging success, and behavioral patterns of these animals (Di lorio and Clark 2009; Forney et al. 2017; Kavanagh et al. 2019). Continued survey effort in the area, especially during winter and early spring, may provide more sightings of blue whales and offer further insights into life history information critical to the management of this endangered species.

\section{Abbreviations}

CETAP: Cetacean and Turtle Assessment Program; EEZ: Exclusive Economic Zone; HARP: High-frequency Acoustic Recording Package; km: Kilometers; m: Meters; mm: Millimeter; MICS: Mingan Island Cetacean Study; U.S.: United States

\section{Acknowledgements}

Bob Kenney provided a valuable review of this manuscript. We thank aerial observer Shannon Coates, pilots Stan Huddle and John Estes from Orion Aviation, and our boat captain Joe DelCampo from the fishing vessel Capt' Cheryl.

\section{Authors' contributions}

DTE - field work, analysis, writing; TP - field work, writing; JMA - field work, analysis, writing; AGE - field work, analysis, writing; MPC - field work, analysis, writing; MFR - field work, writing; JTB - field work, writing. The author(s) read and approved the final manuscript.

\section{Funding}

This project is funded by U.S. Fleet Forces Command and managed by Naval Facilities Engineering Command Atlantic as part of the U.S. Navy's Marine Species Monitoring program

\section{Availability of data and materials}

The datasets generated and/or analyzed during the current study are available in the Ocean Biogeographic Information System Spatial Ecology Analysis of Megavertebrate Populations (OBIS-SEAMAP) repository (http:// seamap.env.duke.edu/partner/NAVY). Additional details may be requested from the corresponding author upon reasonable request.

\section{Ethics approval and consent to participate}

All survey methods were conducted under scientific research permit \#16239 issued to Dan Engelhaupt by the National Marine Fisheries Service under the
Marine Mammal Protection Act and Endangered Species Act. Prior to surveys, procedures outlined in the permit were reviewed and approved by an Institutional Animal Care and Use Committee as part of the Animal Welfare Act. Consent to participate is not applicable.

\section{Consent for publication}

Not applicable.

\section{Competing interests}

JMA, DTE, MPC, and MFR are employed by HDR; AGE is self-employed via Amy Engelhaupt Consulting; TP is self-employed; and JTB is employed by NAVFAC Atlantic. The authors declare that they have no competing interests.

\section{Author details}

${ }^{1} \mathrm{HDR}, 4144$ Hermitage Point, Virginia Beach, VA 23455, USA. ${ }^{2}$ West End, NC, USA. ${ }^{3}$ Amy Engelhaupt Consulting, 4173 Ewell Rd, Virginia Beach, VA 23455 USA. ${ }^{4}$ Naval Facilities Engineering Command Atlantic, 6506 Hampton Blvd, Norfolk, VA 23508, USA.

Received: 17 October 2019 Accepted: 14 May 2020

Published online: 27 May 2020

\section{References}

Aschettino JM, Engelhaupt DT, Engelhaupt AG, DiMatteo A, Pusser T, Richlen MF, Bell JT. Satellite telemetry reveals spatial overlap between vessel high-traffic areas and humpback whales (Megaptera novaeangliae) near the mouth of the Chesapeake Bay. Front Mar Sci. 2020;7:121.

Atkinson LP, O'Malley PG, Yoder JA, Paffenhofer GA. The effect of summertime shelf break upwelling on nutrient flux in southeastern continental shelf waters. J Mar Res. 1984;42(4):969-93.

Bailey H, Mate BR, Palacios DM, Irvine L, Bograd SJ, Costa DP. Behavioural estimation of blue whale movements in the Northeast Pacific from state-space model analysis of satellite tracks. Endanger Species Res. 2009;10:93-106.

Baughman JL. On the occurrence of a rorqual whale on the Texas coast. J Mammal. 1946;27:392-3.

Calambokidis J, Schorr GS, Steiger GH, Francis J, Bakhtiari M, Marshal G, Oleson EM, Gendron D, Robertson K. Insights into the underwater diving, feeding and calling behavior of blue whales from a suction-cup-attached videoimaging tag (CRITTERCAM). Mar Technol Soc J. 2007;41:19-29.

CETAP (Cetacean and Turtle Assessment Program, University of Rhode Island). A characterization of marine mammals and turtles in the mid- and north Atlantic areas of the U.S. outer continental shelf. Washington, DC: Bureau of Land Management; 1982 Final Report. Contract AA551-CT8-48. p. 1-586. 
Clark CW. Application of U.S. Navy underwater hydrophone arrays for scientific research on whales. Rep Int Whaling Comm. 1995;45:210-2.

Debich AJ, Baumann-Pickering S, Širović A, Hildebrand JA, Brewer AM, Frasier KE, Gresalfi RT, Herbert ST, Johnson SC, Rice AC, Varga LM, Wiggins SM, Hodge LEW, Stanistreet JE, Read AJ. Passive acoustic monitoring for marine mammals in the Virginia Capes Range Complex October 2012 - April 2015. Final report. Marine Physical Laboratory Technical Memorandum 559. In: Submitted to Naval Facilities Engineering Command Atlantic, Norfolk, Virginia; 2016.

Di lorio L, Clark CW. Exposure to seismic survey alters blue whale acoustic communication. Biol Lett. 2009:6:51-4.

Filippino KC, Bernhardt PW, Mulholland MR. Chesapeake Bay plume morphology and the effects on nutrient dynamics and primary productivity in the coastal zone. Estuaries Coasts. 2009;32(3):410-24.

Forney KA, Southall BL, Slooten E, Dawson S, Read AJ, Baird RW, Brownell RL Jr. Nowhere to go: noise impact assessments for marine mammal populations with high site fidelity. Endanger Species Res. 2017;32:391-413.

Hodge L, Stanistreet J, Read A. Annual report 2014: passive acoustic monitoring for marine mammals off of Virginia, North Carolina, and Florida using highfrequency acoustic recording packages. Final report. Prepared for U.S. Fleet Forces Command. Submitted to Naval Facilities Engineering Command Atlantic, Norfolk, Virginia, under contract no. N62470-10-3011 issued to HDR, Virginia Beach, Virginia. 2015.

Hodge L, Stanistreet J, Read A. Passive acoustic monitoring for marine mammals at site A in Norfolk Canyon, June 2014-April 2015. Technical report. Prepared for U.S. Fleet Forces Command. Submitted to Naval Facilities Engineering Command Atlantic, Norfolk, Virginia, under contract no. N62470-10-3011 issued to HDR, Virginia Beach, Virginia. 2016.

Jefferson TA, Webster MA, Pitman RL. Marine mammals of the world: a comprehensive guide to their identification, second edition. the Far East: Academic Press; 2018

Kavanagh AS, Nykänen M, Hunt W, Richardson N, Jessopp MJ. Seismic surveys reduce cetacean sightings across a large marine ecosystem. Sci Rep. 2019;9: 19164.

Kenney RD, Vigness-Raposa KJ. Marine mammals and sea turtles of Narragansett Bay, Block Island Sound, Rhode Island Sound, and nearby waters: an analysis of existing data for the Rhode Island Ocean Special Area Management Plan. In: Rhode Island Ocean Special Area Management Plan. Volume 2 Appendix A: technical reports for the Rhode Island Ocean Special Area Management Plan. Wakefield: Rhode Island Coastal Resources Management Council; 2010 p. 701-1037. http://www.crmc.ri.gov/samp_ocean/finalapproved/TechRep10Kenney-MMT.pdf.

Lee TN, Yoder JA, Atkinson LP. Gulf Stream frontal eddy influence on productivity of the southeast U.S. continental shelf. J Geophys Res. 1991;C12(22):19122,205 .

Lesage V, Gavrilchuk K, Andrews R, Sears R. Foraging areas, migratory movements, and wintering destinations of blue whales from the Western North Atlantic. Endanger Species Res. 2017;34:27-43.

Lowry GH. The mammals of Louisiana and its adjacent waters. Baton Rouge: Louisiana State University Press; 1974.

Malone TC, Ducklow HW. Microbial biomass in the coastal plume of the Chesapeake Bay: Phytoplankton-bacterioplankton relationships. Limnol Oceanogr. 1990:35:296-312.

Mitchell ED. Present status of northwest Atlantic fin and other whale stocks. In: Schevill WE, editor. The whale problem: a status report. Cambridge: Harvard University Press; 1974. p. 108-69.

Oleson EM, Calambokidis J, Burgess WC, McDonald MA, LeDuc CA, Hildebrand JA. Behavioral context of call production by eastern North Pacific blue whales. Mar Ecol Prog Ser. 2007;330:269-84.

Rafter MA, Frasier KE, Trickey JS, Rice AC, Hildebrand JA, Thayre BJ, Wiggins SM, Baumann-Pickering S, Širović A. Passive acoustic monitoring for marine mammals in the Jacksonville Range Complex April 2016 - June 2017. Marine Physical Laboratory Technical Memorandum 623. Submitted to Naval Facilities Engineering Command (NAVFAC) Atlantic, Norfolk, Virginia; 2018a.

Rafter MA, Frasier KE, Trickey JS, Rice AC, Reagan E, Wiggins SM, Hildebrand JA, Baumann-Pickering S. Passive acoustic monitoring for marine mammals off Cape Hatteras May 2017-2018. Final report. Marine Physical Laboratory Technical Memorandum 635. 2018b.

Reeves RR, Smith TD, Josephson EA, Clapham PJ, Woolmer G. Historical observations of humpback and blue whales in the North Atlantic Ocean: clues to migratory routes and possibly additional feeding grounds. Mar Mamm Sci. 2004;20:774-86.

Rockwood RC, Calambokidis J, Jahncke J. High mortality of blue, humpback and fin whales from modeling of vessel collisions on the U.S. West Coat suggests population impacts and insufficient protection. PLoS One. 2017;12(8): e0183052.

Schmidly DJ. Marine mammals of the southeastern United States coast and the Gulf of Mexico. Washington, DC: U.S. Fish and Wildlife Service, Office of Biological Sciences; 1981. Report FWS/OBS-80/41.

Sears R, Williamson JM, Wenzel FW, Bérubé M, Gendron D, Jones P. Photographic identification of the blue whale (Balaenoptera musculus) in the Gulf of St. Lawrence, Canada. Rept International Whaling Comm Spec Issue. 1990;12: 335-42.

Sergeant DE. Populations of large whale species in the western North Atlantic with special reference to the fin whale. In: Fish. Res. Bd. Canada. Arctic Biol. Sta. Circular No. 9; 1966

Silva MA, Prieto R, Jonsen I, Baumgartner MF, Santos RS. North Atlantic blue and fin whales suspend spring migration to forage in middle latitudes: building up energy reserves for the journey? PLoS One. 2013;8(10):e76507.

Širović A, Hildebrand JA, Wiggins SM. Blue and fin whale call source levels and propagation range in the Southern Ocean. J Acoust Soc Am. 2007;122(2): 1208-15.

Southall BL, DeRuiter SL, Friedlaender A, Stimpert AK, Goldbogen JA, Hazen E, Casey C, Fregosi S, Cade DE, Allen AN, Harris CM, Schorr G, Moretti D, Guan $\mathrm{S}$, Calambokidis J. Behavioral responses of individual blue whales (Balaenoptera musculus) to mid-frequency military sonar. J Exp Biol. 2019;222: 190637.

True FW. The whalebone whales of the western North Atlantic compared with those occurring in European waters; with some observations on the species of the North Pacific. Smithson Contrib Knowl. 1904;33:1-332.

Tulloch VJD, Plagányi ÉE, Brown C, Richardson AJ, Matear R. Future recovery of baleen whales is imperiled by climate change. Glob Chang Biol. 2019;25: 1263-81.

Visser F, Hartman KL, Pierce GJ, Valavanis VD, Huisman J. Timing of migratory baleen whales at the Azores in relation to the North Atlantic spring bloom Mar Ecol Prog Ser. 2011;440:267-79.

Wenzel FW, Mattila DK, Clapham PJ. Balaenoptera musculus in the Gulf of Maine. Mar Mamm Sci. 1988;4:172-5.

\section{Publisher's Note}

Springer Nature remains neutral with regard to jurisdictional claims in published maps and institutional affiliations.
Ready to submit your research? Choose BMC and benefit from:
- fast, convenient online submission
- thorough peer review by experienced researchers in your field
- rapid publication on acceptance
- support for research data, including large and complex data types
- gold Open Access which fosters wider collaboration and increased citations
- maximum visibility for your research: over $100 \mathrm{M}$ website views per year
At BMC, research is always in progress.
Learn more biomedcentral.com/submissions 